\title{
Editorial \\ Advances in Neuromodulation for Chronic Pain
}

\author{
Maarten Moens $1,2,3,4,5, * \mathbb{D}$ and Lisa Goudman $1,2,3,4,6$ (D)
}

1 Department of Neurosurgery, Universitair Ziekenhuis Brussel, Laarbeeklaan 101, 1090 Brussels, Belgium; lisa.goudman@vub.be

2 STIMULUS Consortium (reSearch and TeachIng neuroModULation Uz bruSsel), Vrije Universiteit Brussel, Laarbeeklaan 103, 1090 Brussels, Belgium

3 Center for Neurosciences (C4N), Vrije Universiteit Brussel, Laarbeeklaan 103, 1090 Brussels, Belgium

4 Pain in Motion (PAIN) Research Group, Department of Physiotherapy, Human Physiology and Anatomy, Faculty of Physical Education and Physiotherapy, Vrije Universiteit Brussel, Laarbeeklaan 103, 1090 Brussels, Belgium

5 Department of Radiology, Universitair Ziekenhuis Brussel, Laarbeeklaan 101, 1090 Brussels, Belgium

6 Research Foundation-Flanders (FWO), 1090 Brussels, Belgium

* Correspondence: Maarten.moens@uzbrussel.be; Tel.: +32-24775514

\section{check for}

updates

Citation: Moens, M.; Goudman, L.

Advances in Neuromodulation for Chronic Pain. J. Clin. Med. 2022, 11, 874. https://doi.org/10.3390/ jcm11030874

Received: 28 January 2022

Accepted: 2 February 2022

Published: 7 February 2022

Publisher's Note: MDPI stays neutral with regard to jurisdictional claims in published maps and institutional affiliations.

Copyright: (C) 2022 by the authors. Licensee MDPI, Basel, Switzerland. This article is an open access article distributed under the terms and conditions of the Creative Commons Attribution (CC BY) license (https:// creativecommons.org/licenses/by/ $4.0 /)$.
In the past decade, neuromodulation as a treatment option for pain took a huge interest in innovating and developing more effective paradigms to conquer chronic pain syndromes. Several device-developing companies introduced, in collaboration with clinical researchers and governmental authorities, randomized clinical and non-inferiority trials challenging their new paradigms over standard spinal cord stimulation [1-6].

These trials demonstrated impressive reductions in pain intensities by the new paradigms compared to the standard SCS, resulting in introducing terms such as "superiority" and "remitter". Despite these monumental steps in the field of neuromodulation, predicting a good outcome for a single individual patient remains a challenge in daily practice. The challenge is not the know-how in introducing very specific statistical analyses in the world of neuromodulation but in defining what a good outcome means [7]. There are conflicting interests and definitions of success between patients, implanting physicians, companies, and authorities. For many years the primary outcome measurements in leading research were based on pain intensities and the amount of reducing painkillers. This oversimplification of a very complex syndrome, such as chronic pain, drove wedges between the different stakeholders. If we keep in mind that a personalized treatment for every chronic pain patient is the ultimate goal to reach for more independence for those patients, the definition of success by neuromodulation should be aligned to every stakeholder, including the patients. The first step towards the holy grail is to walk the extra mile for every patient, even for those who do not respond anymore to the initial paradigm. Salvage strategies and algorithms are gaining interest from researchers and clinicians [8-13]. Salvage therapy should not only consist of converting patients towards new paradigms but also introducing extra tools to regain freedom and independence in terms of patient empowerment. Within this evolution, the recognition that pain is much more than a biological problem is a mainstay. The social and professional dimensions of a chronic pain syndrome remain understudied. The other step is more an evolution in progress; several high-level studies immerse the original data in advanced statistical modelling and analyses. Coming from well-balanced and clinically relevant hypotheses, the next level of mathematical solutions is giving answers and predictions to clinicians in daily practice. The gap between the "sterile" clinical trials and real-world daily routine care should be bridged by clear interpretations, flowcharts, and prediction charts.

Thus, "advances in neuromodulation" are fights on different battlefields, resulting in a better life for chronic pain patients with a joint win for physicians, companies, and society.

Funding: This research received no external funding. 
Acknowledgments: We would like to thank the authors for their valuable scientific papers, reviewers for their improvement suggestions.

Conflicts of Interest: The authors declare no conflict of interest.

\section{References}

1. Kapural, L.; Yu, C.; Doust, M.W.; Gliner, B.E.; Vallejo, R.; Sitzman, B.T.; Amirdelfan, K.; Morgan, D.M.; Brown, L.L.; Yearwood, T.L.; et al. Novel 10-kHz High-frequency Therapy (HF10 Therapy) Is Superior to Traditional Low-frequency Spinal Cord Stimulation for the Treatment of Chronic Back and Leg Pain: The SENZA-RCT Randomized Controlled Trial. Anesthesiology 2015, 123, 851-860. [CrossRef] [PubMed]

2. Mekhail, N.; Levy, R.M.; Deer, T.R.; Kapural, L.; Li, S.; Amirdelfan, K.; Hunter, C.W.; Rosen, S.M.; Costandi, S.J.; Falowski, S.M.; et al. Long-term safety and efficacy of closed-loop spinal cord stimulation to treat chronic back and leg pain (Evoke): A double-blind, randomised, controlled trial. Lancet Neurol. 2020, 19, 123-134. [CrossRef]

3. Veizi, E.; Hayek, S.M.; North, J.; Brent Chafin, T.; Yearwood, T.L.; Raso, L.; Frey, R.; Cairns, K.; Berg, A.; Brendel, J.; et al. Spinal Cord Stimulation (SCS) with Anatomically Guided (3D) Neural Targeting Shows Superior Chronic Axial Low Back Pain Relief Compared to Traditional SCS-LUMINA Study. Pain Med. 2017, 18, 1534-1548. [CrossRef] [PubMed]

4. $\quad$ Deer, T.; Slavin, K.V.; Amirdelfan, K.; North, R.B.; Burton, A.W.; Yearwood, T.L.; Tavel, E.; Staats, P.; Falowski, S.; Pope, J.; et al. Success Using Neuromodulation with BURST (SUNBURST) Study: Results from a Prospective, Randomized Controlled Trial Using a Novel Burst Waveform. Neuromodulation 2018, 21, 56-66. [CrossRef] [PubMed]

5. North, R.B.; Parihar, H.S.; Spencer, S.D.; Spalding, A.F.; Shipley, J. Cost-Effectiveness Model Shows Superiority of Wireless Spinal Cord Stimulation Implantation without a Separate Trial. Neuromodulation 2021, 24, 596-603. [CrossRef] [PubMed]

6. Fishman, M.; Cordner, H.; Justiz, R.; Provenzano, D.; Merrell, C.; Shah, B.; Naranjo, J.; Kim, P.; Calodney, A.; Carlson, J.; et al. Twelve-Month results from multicenter, open-label, randomized controlled clinical trial comparing differential target multiplexed spinal cord stimulation and traditional spinal cord stimulation in subjects with chronic intractable back pain and leg pain. Pain Pract. 2021, 21, 912-923. [CrossRef] [PubMed]

7. Goudman, L.; Moens, M. Moving Beyond a Pain Intensity Reporting: The Value of Goal Identification in Neuromodulation. Neuromodulation 2020, 23, 1057-1058. [CrossRef] [PubMed]

8. Rigoard, P.; Ounajim, A.; Goudman, L.; Banor, T.; Heroux, F.; Roulaud, M.; Babin, E.; Bouche, B.; Page, P.; Lorgeoux, B.; et al. The Challenge of Converting "Failed Spinal Cord Stimulation Syndrome" Back to Clinical Success, Using SCS Reprogramming as Salvage Therapy, through Neurostimulation Adapters Combined with 3D-Computerized Pain Mapping Assessment: A Real Life Retrospective Study. J. Clin. Med. 2022, 11, 272. [CrossRef] [PubMed]

9. Rigoard, P.; Ounajim, A.; Goudman, L.; Bouche, B.; Roulaud, M.; Page, P.; Lorgeoux, B.; Baron, S.; Nivole, K.; Many, M.; et al. The Added Value of Subcutaneous Peripheral Nerve Field Stimulation Combined with SCS, as Salvage Therapy, for Refractory Low Back Pain Component in Persistent Spinal Pain Syndrome Implanted Patients: A Randomized Controlled Study (CUMPNS Study) Based on 3D-Mapping Composite Pain Assessment. J. Clin. Med. 2021, 10, 5094. [CrossRef] [PubMed]

10. Pendem, K.; Jassal, N. Dorsal Root Ganglion Stimulation as Treatment for Complex Regional Pain Syndrome of the Foot Refractory to Spinal Cord Stimulation: A Case Report. Cureus 2021, 13, e12753. [CrossRef] [PubMed]

11. Kapural, L.; Sayed, D.; Kim, B.; Harstroem, C.; Deering, J. Retrospective Assessment of Salvage to $10 \mathrm{kHz}$ Spinal Cord Stimulation (SCS) in Patients Who Failed Traditional SCS Therapy: RESCUE Study. J. Pain Res. 2020, 13, 2861-2867. [CrossRef] [PubMed]

12. Chang, K.; Hagedorn, J.M. Salvage of a Passive Recharge Burst Spinal Cord Stimulation Implant With $10 \mathrm{kHz}$ Spinal Cord Stimulation for Failed Back Surgery Syndrome: A Case Report. A A Pract. 2020, 14, e01345. [CrossRef] [PubMed]

13. De Jaeger, M.; Goudman, L.; Brouns, R.; De Smedt, A.; Linderoth, B.; Eldabe, S.; Discover, c.; Moens, M. The Long-Term Response to High-Dose Spinal Cord Stimulation in Patients With Failed Back Surgery Syndrome After Conversion From Standard Spinal Cord Stimulation: An Effectiveness and Prediction Study. Neuromodulation 2021, 24, 546-555. [CrossRef] 